\title{
FUZZY METHODS IN RISK ESTIMATION OF THE SHIP SYSTEM FAILURES BASED ON THE EXPERT JUDGMENTS
}

\section{ROZMYTE METODY ESTYMACJI RYZYKA USZKODZEŃ SYSTEMÓW OKRĘTOWYCH NA PODSTAWIE OPINII EKSPERTÓW}

\section{Hoang Nguyen}

\author{
Gdynia Maritime University
}

\begin{abstract}
The paper presents the fuzzy methods in failure modes and effects analysis (FMEA) for estimating the risk of the ship system failures based on the expert judgments. It provides an appropriate representation of the uncertain and ambiguous notions expressed in the natural language. An example of fuzzy intuitionistic FMEA analysis is illustrated in estimating the risk of tanker system failures. The results show that the proposed method in comparison with the traditional FMEA is more effective and useful in estimating the risk of ship system failures based on the expert opinions, available in such cases.
\end{abstract}

Keywords: Intuitionistic fuzzy set, risk estimation, expert judgment, ship system failure.

Streszczenie: Praca przedstawia rozmyte metody $w$ analizy rodzajów $i$ skutków uszkodzeń (FMEA) do estimacji ryzyka uszkodzeń systemów okrętowych. Zapewnia ona odpowiednia reprezentacje niepewnych $i$ niejasnych pojęć wyrażonych $w$ języku naturalnym. Przyktad zastosowania rozmytej, intuicjonistycznej analizy FMEA zostat zilustrowany $w$ estymacji ryzyka uszkodzeń systemów tankowca. Uzyskane wyniki wskazuja, że proponowana metoda $w$ porównaniu z tradycyjna analiza FMEA, jest bardziej skuteczna w estymacji ryzyka uszkodzeń systemów okrętowych, na podstawie opinii ekspertów.

Stowa kluczowe: Intuicjonistyczne zbiory rozmyte, estymacja ryzyka, opinia ekspertów, uszkodzenie systemu okrętowego. 
Fuzzy methods in risk estimation of the ship system failures based on the expert... Rozmyte metody estymacji ryzyka uszkodzeń systemów okrętowych na podstawie...

\section{Introduction}

Risk is an evaluation (often subjective) of the hazard resulting from the possible adverse consequences after making certain decisions. It is important to note that risk is inherent in every human activity. In many cases, however, it is so small that it does not have any implications. However, in some situations such conduct can lead to unpleasant consequences that could easily be avoided. In maritime transport, the risk assessment of damage to some, especially key sea-going ship systems, is important, as their consequences can be serious accidents or even marine disasters. For example, loss of propulsion function by a ship is one of the most dangerous categories of hazard events. Under certain external conditions, this can lead to loss of the ship and environmental pollution. The consequences of loss of propulsion by the ship are events classified by the International Maritime Organization as accidents or incidents. Consequently, estimating the risk of damage to ship systems based on failure modes and effects analysis (FMEA) is necessary to make appropriate inspection and maintenance decisions, which in turn will increase system reliability and shipping safety.

Estimating the risk of such a system encounters difficulties due to system complexity and negligible historical data. In such cases, subjective evaluations prove to be useful on the basis of expert opinion. However, such assessments to some extent are subject to imprecision or uncertainty due to the level of education, experience and knowledge of the considered field.

Among the risk assessment methods, FMEA is the most widely used engineering technique in many industries that can be used to identify and eliminate known or potential failures to improve the reliability and safety of complex systems. It is also intended to provide information for risk management decisions. Traditional FMEA defines the risk priorities of failures using the so-called Risk Priority Number (RPN), which is defined as the simple product of probabilities of failure occurrence (O), severity (S), and difficulty of detecting (D) failure. Determining these probabilities in practice encounters the difficulty of missing data. In such cases, we must rely on subjective assessments made by persons with practical knowledge in the area under consideration, i.e. experts. However, their practical knowledge can to some extent contain ambiguity and uncertainty. On the other hand, experts prefer to formulate their opinions in linguistic terms.

Traditional FMEA analysis seems insufficient to extract important information from subjective evaluations in these situations. Consequently, fuzzy theory was introduced into the traditional FMEA, which makes it more flexible in describing them. Wang et al. [14] proposed a new, fuzzy FMEA that assesses risk factors and their relative weight in linguistic form. 
Abdelgawad and Fayek [1] used a combination of fuzzy FMEA and fuzzy analytical hierarchical process (AHP) to develop a risk management method in construction. Brandowski et al. [3] developed a fuzzy-neuron model of the seagoing ship risk estimation. Laarhoven and Pedrycz [8] introduced the fuzzy AHP (FAHP), where each evaluation of pairwise comparison is represented by the fuzzy triangular membership function to a given set.

Because this feature describes only the membership degree of an item to a fuzzy set, it cannot be used to express support and opposition opinions that occur simultaneously in many practical situations. Decision makers also may not be able to accurately assess their ratings or preferences because of insufficient knowledge of the domain under consideration or cannot clearly distinguish the extent to which one alternative is better than the other. In other words, there is some degree of hesitation in expert opinions. Atanassov [2] extended Zadeh's fuzzy set to an intuitionistic fuzzy set (IFS), characterized by degree of membership, degree of non-membership and degree of hesitation, to describe such situations and to understand more about human perception and cognition. IFSs have been attracting rapidly increasing attention from researchers and have been used in many areas such as decision making [6], [12], fuzzy cognitive maps [10], medical diagnosis [5], fault diagnosis and pattern recognition $[9,13]$. Xu and Liao [15] have extended the classic AHP and FAHP to intuitionistic fuzzy IFAHPs to solve comprehensive decision-making criteria.

In this article, a methodology for estimating the risk of ship system failures is proposed. Estimation is fully based on expert opinion. It is adapted to their knowledge gained from long-term professional work in the operation of ship systems and their ability to express this knowledge. The presented method has been developed for use in decision-making procedures for predicting risks during ship operation.

\section{Theoretical background}

In 1983 Atanassov generalized the concept of fuzzy sets given by Zadeh [16] by using membership function and non-membership function for any elements of the universe of discourse. An Atanassov's Intuitionistic Fuzzy Set (IFS) is described by [2]:

$$
\mathrm{A}=\left\{\left(\mathrm{x}, \mu_{\mathrm{A}}(\mathrm{x}), v_{\mathrm{A}}(\mathrm{x})\right) \mid \mathrm{x} \in \mathrm{X}\right\},
$$

where $\mu_{\mathrm{A}}(\mathrm{x})$ denotes a degree of membership and $v_{\mathrm{A}}(\mathrm{x})$ denotes a degree of nonmembership of $\mathrm{x}$ to $\mathrm{A}, \mu_{\mathrm{A}}: \mathrm{X} \rightarrow[0,1]$ and $v_{\mathrm{A}}: \mathrm{X} \rightarrow[0,1]$ such that

$$
0 \leq \mu_{\mathrm{A}}(\mathrm{x})+v_{\mathrm{A}}(\mathrm{x}) \leq 1, \forall \mathrm{x} \in \mathrm{X} .
$$


Fuzzy methods in risk estimation of the ship system failures based on the expert... Rozmyte metody estymacji ryzyka uszkodzeń systemów okrętowych na podstawie...

The intuitionistic fuzzy index or the hesitation margin of an element $x$ to the intuitionistic fuzzy set A was introduced as:

$$
\pi_{\mathrm{A}}(\mathrm{x})=1-\mu_{\mathrm{A}}(\mathrm{x})-v_{\mathrm{A}}(\mathrm{x}) .
$$

It is obvious, that $0 \leq \pi_{A}(x) \leq 1, \forall x \in X$.

If $\pi_{\mathrm{A}}(\mathrm{x})=0, \forall \mathrm{x} \in \mathrm{X}$, then $\mu_{\mathrm{A}}(\mathrm{x})+v_{\mathrm{A}}(\mathrm{x})=1$ and the intuitionistic fuzzy set $\mathrm{A}$ reduces to an ordinary fuzzy set, which is defined as: $A=\left\{\left(x, \mu_{A}(x)\right) \mid x \in X\right\}$. The trapezoidal and triangular fuzzy numbers are the most popular fuzzy sets used in various applications.

The concept of a complement of an IFS A, denoted by $\mathrm{A}^{\mathrm{c}}$ is defined as:

$$
\mathrm{A}^{\mathrm{c}}=\left\{\left(\mathrm{x}, v_{\mathrm{A}}(\mathrm{x}), \mu_{\mathrm{A}}(\mathrm{x}), \pi_{\mathrm{A}}(\mathrm{x})\right) \mid \mathrm{x} \in \mathrm{X}\right\} .
$$

The operations of addition $\oplus$ and multiplication $\otimes$ on intuitionistic fuzzy values (IFVs) were defined by Atanassov [2] as follows. Let $A=\left\langle\mu_{A}, v_{A}\right\rangle$ and $B=$ $\left\langle\mu_{\mathrm{B}}, v_{\mathrm{B}}\right\rangle$ be IFVs, then the following operators were defined:

$$
\begin{aligned}
& A \oplus B=\left(\mu_{A}+\mu_{B}-\mu_{A} \mu_{B}, v_{A} v_{B}\right), \\
& A \otimes B=\left(\mu_{A} \mu_{B}, v_{A}+v_{B}-v_{A} v_{B}\right), \\
& \lambda A=\left(1-\left(1-\mu_{A}\right)^{\lambda}, v_{A}^{\lambda}\right),(\lambda>0), \\
& A^{\lambda}=\left(\mu_{A}^{\lambda}, 1-\left(1-v_{A}\right)^{\lambda}\right),(\lambda>0) .
\end{aligned}
$$

The operations (5) - (8) are used to aggregate local criteria for solving MCDM problems in the intuitionistic fuzzy setting. Let $A_{1}, \ldots, A_{m}$ be IFVs representing the values of local criteria and $w_{1}, \ldots, w_{m} ; \sum_{j=1}^{m} w_{j}=1$ be their weights. Then intuitionistic fuzzy weighted arithmetic mean (IFWA) can be obtained using operations (5) and (7) as follows:

$$
\begin{aligned}
& \operatorname{IFWA}_{w}\left(A_{1}, \ldots, A_{m}\right)=w_{1} A_{1} \oplus \ldots \oplus w_{m} A_{m} \\
& =\left\langle 1-\prod_{j=1}^{m}\left(1-\mu_{A}\right)^{w_{j}}, \quad \prod_{j=1}^{m}\left(v_{A}\right)^{w_{j}}\right\rangle
\end{aligned}
$$

Intuitionistic fuzzy weighted geometric mean (IFWG) can be obtained using operations (6) and (8) as follows:

$$
\begin{gathered}
I^{I F W G} G_{w}\left(A_{1}, \ldots, A_{m}\right)=w_{1} A_{1} \otimes \ldots \otimes w_{m} A_{m} \\
=\left\langle\prod_{j=1}^{m}\left(\mu_{A}\right)^{w_{j}}, 1-\prod_{j=1}^{m}\left(1-v_{A}\right)^{w_{j}}\right\rangle
\end{gathered}
$$

These aggregation operators provide IFVs, are idempotent and currently are most popular in the solution of decision-making problems in the intuitionistic fuzzy 
setting. An important problem is the comparison of IFVs to choose the best alternative when the final scores of alternatives are presented by IFVs. The specific methods were developed to compare IFVs. Chen and Tan [4] proposed to use the so-called score function $\mathrm{S}$ (or net membership). In addition to the above score function, Hong and Choi [7] introduced the so-called accuracy function $\mathrm{H}$ and showed that the relation between functions $\mathrm{S}$ and $\mathrm{H}$ is similar to the relation between mean and variance in statistics. In [11] Szmidt et al. proposed a knowledge measure of IFV, taking into account all its parameters, i.e. membership, non-membership and hesitancy degrees. Since these methods are rather of heuristic nature, there have been different other definitions of the score function proposed in the literature.

In order to rank the IFVs, we utilize the membership knowledge measure $\mathrm{K}_{\mathrm{F}}(\alpha)$ proposed in [9], which is well interpreted and simply in computation. Let $\alpha=\left\langle\mu_{\alpha}, v_{\alpha}\right\rangle$ be an IFV in finite universe of discourse $\mathrm{X}$. The score function of $\alpha \in \mathrm{X}$ is defined as:

where

$$
S(\alpha)=\left\{\begin{array}{c}
K_{F}(\alpha) \text { for } \mu_{\alpha} \geq v_{\alpha} \\
-K_{F}(\alpha) \text { for } \mu_{\alpha}<v_{\alpha}
\end{array},\right.
$$

$$
\mathrm{K}_{\mathrm{F}}(\alpha)=\frac{1}{\sqrt{2}} \sqrt{\mu_{\alpha}^{2}+v_{\alpha}^{2}+\left(\mu_{\alpha}+v_{\alpha}\right)^{2}}
$$

The score function $S(\alpha),-1 \geq S(\alpha) \geq 1$ measures amount of knowledge conveyed by linguistic evaluation presented in form of IFVs. In the case, when the positive information is bigger than negative one, i.e. for $\mu_{\alpha} \geq v_{\alpha}$ (the supporting evidence is larger than the against one), the score function sets the plus sign to the knowledge measure. In the contrary, the minus one is assigned to the score function for $\mu_{\alpha}<v_{\alpha}$. Naturally, that the positive information is preferred to than negative one, so the larger value of score function $S(\alpha)$, the higher rank of IFV $\alpha$.

\section{Methodology of the intuitionistic fuzzy FMEA}

Usually, the risk factors $\mathrm{O}, \mathrm{S}$ and $\mathrm{D}$ are evaluated by experts in linguistic terms. The linguistic terms and their related intuitionistic fuzzy numbers are shown in Tables 1-3. For example, experts revealed their opinions on the occurrence probability of the ship system failures in the form of linguistic values chosen from the given linguistic set (Table 1): very high $(\mathrm{VH})$, high $(\mathrm{H})$, moderate $(\mathrm{M})$, low $(\mathrm{L})$ and very low (VL). We take into account period of practical experience of experts as a factor of their hesitancy degree in judgments as follows:

$$
\pi_{\mathrm{j}}=1 / 2^{\mathrm{p}_{\mathrm{j}}}
$$


Fuzzy methods in risk estimation of the ship system failures based on the expert... Rozmyte metody estymacji ryzyka uszkodzeń systemów okrętowych na podstawie...

where $p_{j}$ denotes the expert's professional experience in years. The more experience, the less uncertainty he/she has. The rating of failure mode $F_{i}$ made by the expert $E_{j}$ on the risk factor $\mathrm{O}$ is represented by $R_{i j}^{o}=\left\langle\mu_{i j}^{o}, v_{i j}^{o}\right\rangle$, where $\mu_{i j}^{o}$ is the membership degree of the failure mode to the risk factor $\mathrm{O}$, related to the linguistic rating. The non-membership degree is determined as:

$$
v_{\mathrm{ij}}^{\mathrm{o}}=1-\mu_{\mathrm{ij}}^{\mathrm{o}}-\pi_{\mathrm{ij}}^{\mathrm{o}}, 0 \leq v_{\mathrm{ij}}^{\mathrm{o}} \leq 1 .
$$

Hence, the intuitionistic fuzzy numbers related to the linguistic values of the given set should be suitable to hesitancy degree (knowledge level) of the experts.

Suppose there are $\mathrm{n}$ failure modes $F_{i},(i=1, \ldots, n)$ of the seagoing ship systems, and $m$ experts $E_{j},(j=1, \ldots, m)$ evaluating the failure modes on the risk factors in the linguistic values.

Let $R_{i j}^{o}=\left\langle\mu_{i j}^{o}, v_{i j}^{o}\right\rangle, R_{i j}^{S}=\left\langle\mu_{i j}^{s}, v_{i j}^{s}\right\rangle$ and $R_{i j}^{d}=\left\langle\mu_{i j}^{d}, v_{i j}^{d}\right\rangle$ be the IF ratings of $F_{i}$ on the risk factors $\mathrm{O}, \mathrm{S}$ and $\mathrm{D}$ corresponding to the linguistic values; $\omega_{o}, \omega_{s}$ and $\omega_{d}$ be the weights of the three risk factors, $\lambda_{j},(j=1, \ldots, m)$ be the relative importance weights of the experts, $\sum_{j=1}^{m} \lambda_{j}=1$.

Using the intuitionistic fuzzy weighted averaging (IFWA) operator (9) we aggregate the IF ratings of failure mode $F_{i}$ on the risk factors $\mathrm{O}, \mathrm{S}$ and $\mathrm{D}$, respectively:

$$
\begin{aligned}
& \mathrm{R}_{\mathrm{i}}^{\mathrm{o}}=\mathrm{IFWA}_{\lambda}\left(\mathrm{R}_{\mathrm{i} 1}^{\mathrm{o}}, \mathrm{R}_{\mathrm{i} 2}^{\mathrm{o}}, \ldots, \mathrm{R}_{\mathrm{im}}^{\mathrm{o}}\right)=\lambda_{1} \mathrm{R}_{\mathrm{i} 1}^{\mathrm{o}} \oplus \ldots \oplus \lambda_{\mathrm{m}} \mathrm{R}_{\mathrm{im}}^{\mathrm{o}} \\
& =\left\langle 1-\prod_{j=1}^{m}\left(1-\mu_{i j}^{o}\right)^{\lambda_{j}}, \quad \prod_{j=1}^{m}\left(v_{i j}^{o}\right)^{\lambda_{j}}\right\rangle=\left\langle\mu_{i}^{o}, v_{i}^{o}\right\rangle \text {, } \\
& \mathrm{R}_{\mathrm{i}}^{\mathrm{s}}=\mathrm{IFWA}_{\lambda}\left(\mathrm{R}_{\mathrm{i} 1}^{\mathrm{s}}, \mathrm{R}_{\mathrm{i} 2}^{\mathrm{s}}, \ldots, \mathrm{R}_{\mathrm{im}}^{\mathrm{s}}\right)=\lambda_{1} \mathrm{R}_{\mathrm{i} 1}^{\mathrm{s}} \oplus \ldots \oplus \lambda_{\mathrm{m}} \mathrm{R}_{\mathrm{im}}^{\mathrm{s}} \\
& =\left\langle 1-\prod_{j=1}^{m}\left(1-\mu_{i j}^{s}\right)^{\lambda_{j}}, \prod_{j=1}^{m}\left(v_{i j}^{s}\right)^{\lambda_{j}}\right\rangle=\left\langle\mu_{i}^{s}, v_{i}^{s}\right\rangle, \\
& \mathrm{R}_{\mathrm{i}}^{\mathrm{d}}=\operatorname{IFWA}_{\lambda}\left(\mathrm{R}_{\mathrm{i} 1}^{\mathrm{d}}, \mathrm{R}_{\mathrm{i} 2}^{\mathrm{d}}, \ldots, \mathrm{R}_{\mathrm{im}}^{\mathrm{d}}\right)=\lambda_{1} \mathrm{R}_{\mathrm{i} 1}^{\mathrm{d}} \oplus \ldots \oplus \lambda_{\mathrm{m}} \mathrm{R}_{\mathrm{im}}^{\mathrm{d}} \\
& =\left\langle 1-\prod_{j=1}^{m}\left(1-\mu_{i j}^{d}\right)^{\lambda_{j}}, \quad \prod_{j=1}^{m}\left(v_{i j}^{d}\right)^{\lambda_{j}}\right\rangle=\left\langle\mu_{i}^{d}, v_{i}^{d}\right\rangle \text {. }
\end{aligned}
$$

Table 1 Fuzzy ratings for probability of failure occurrence $\left(\right.$ with $\left.\pi_{j}=0.1\right)$.

\begin{tabular}{|l|l|c|}
\hline \multicolumn{1}{|c|}{ Rating } & \multicolumn{1}{|c|}{ Probability of occurrence } & $\begin{array}{c}\text { Intuitionistic fuzzy } \\
\text { number }\end{array}$ \\
\hline Very high $(\mathrm{VH})$ & Failure is almost inevitable & $\langle 0.8,0.1>$ \\
\hline High (H) & Repeated failures & $\langle 0.6,0.3\rangle$ \\
\hline Moderate $(\mathrm{M})$ & Occasional failures & $\langle 0.45,0.45\rangle$ \\
\hline Low (L) & Relatively few failures & $<0.3,0.6>$ \\
\hline Remote (R) & Failure is unlikely & $<0.1,0.8>$ \\
\hline
\end{tabular}


Table 2 Fuzzy ratings for probability of failure severity $\left(\right.$ with $\left.\pi_{j}=0.1\right)$.

\begin{tabular}{|l|l|c|}
\hline \multicolumn{1}{|c|}{ Rating } & \multicolumn{1}{|c|}{ Severity of failure occurrence } & $\begin{array}{c}\text { Intuitionistic } \\
\text { fuzzy number }\end{array}$ \\
\hline $\begin{array}{l}\text { Very serious } \\
\text { casualty (C1) }\end{array}$ & $\begin{array}{l}\text { Loss of the ship, loss of human life and/or } \\
\text { heavy marine environment pollution. }\end{array}$ & $\langle 0.8,0.1>$ \\
\hline $\begin{array}{l}\text { Serious } \\
\text { casualty (C2) }\end{array}$ & $\begin{array}{l}\text { Injuries or human health deterioration, ship } \\
\text { grounding, touching a submarine object, } \\
\text { contact with a solid object, lost seaworthiness } \\
\text { due to defects, necessity of towing or } \\
\text { assistance from the shore and/or marine } \\
\text { environment pollution. }\end{array}$ & $<0.6,0.3>$ \\
\hline Incident I (I1) & $\begin{array}{l}\text { Prolonged hazard to the ship, people and } \\
\text { environment which can cause a sea accident. } \\
\text { After repair by the ship crew, the ship } \\
\text { functionality is not fully restored (lower ship } \\
\text { system operational parameters). }\end{array}$ & $\langle 0.45,0.45>$ \\
\hline Incident II (I2) & $\begin{array}{l}\text { As in I1, but after repair the ship functionality } \\
\text { is fully restored. }\end{array}$ & $<0.3,0.6>$ \\
\hline Incident III (I3) & $\begin{array}{l}\text { Temporary hazard to the ship, people and } \\
\text { environment which can cause a sea accident. } \\
\text { No repair needed. }\end{array}$ & $<0.1,0.8>$ \\
\hline
\end{tabular}

Table 3 Fuzzy ratings for probability of failure detection $\left(\right.$ with $\left.\pi_{\mathrm{j}}=0.1\right)$.

\begin{tabular}{|l|l|c|}
\hline \multicolumn{1}{|c|}{ Rating } & Probability of failure detection & $\begin{array}{c}\text { Intuitionistic fuzzy } \\
\text { number }\end{array}$ \\
\hline Very remote (VR) & Very remote chance & $<0.1,0.8>$ \\
\hline Very low (VL) & Very low chance & $<0.2,0.7>$ \\
\hline Low (L) & Low chance & $<0.3,0.6>$ \\
\hline Moderately low (ML) & Moderately low chance & $<0.4,0.5>$ \\
\hline Moderate (M) & Moderate chance & $<0.45,0.45>$ \\
\hline Moderately high (MH) & Moderately high chance & $<0.5,0.4>$ \\
\hline High (H) & High chance & $<0.6,0.3>$ \\
\hline Very high (VH) & Very high chance & $<0.7,0.2>$ \\
\hline Almost certain (AC) & Almost certainty & $<0.8,0.1>$ \\
\hline
\end{tabular}


Fuzzy methods in risk estimation of the ship system failures based on the expert... Rozmyte metody estymacji ryzyka uszkodzeń systemów okrętowych na podstawie...

The traditional FMEA defines RPNs as the simple product of $\mathrm{O}, \mathrm{S}$ and $\mathrm{D}$ without considering their relative importance weights, whereas the IFRPN is defined as the fuzzy weighted geometric mean of the three risk factors $\mathrm{O}, \mathrm{S}$ and D. This overcomes the drawback that the three risk factors are treated equally. IFRPN of the failure mode $F_{i}$ can be aggregated using the intuitionistic fuzzy weighted geometric (IFWG) operator (10) as follows:

$$
\begin{gathered}
\operatorname{IFRPN}_{\mathrm{i}}=\omega_{0} \mathrm{R}_{\mathrm{i}}^{0} \otimes \omega_{\mathrm{s}} \mathrm{R}_{\mathrm{i}}^{\mathrm{s}} \otimes \omega_{\mathrm{d}} \mathrm{R}_{\mathrm{i}}^{\mathrm{d}} \\
=\left\langle\left(\mu_{\mathrm{i}}^{0}\right)^{\omega_{0}} \cdot\left(\mu_{\mathrm{i}}^{\mathrm{s}}\right)^{\omega_{\mathrm{s}}} \cdot\left(\mu_{\mathrm{i}}^{\mathrm{d}}\right)^{\omega_{\mathrm{d}}}, 1-\left(1-v_{\mathrm{i}}^{0}\right)^{\omega_{0}} \cdot\left(1-v_{\mathrm{i}}^{\mathrm{s}}\right)^{\omega_{\mathrm{s}}} \cdot\left(1-v_{\mathrm{i}}^{\mathrm{d}}\right)^{\omega_{\mathrm{d}}}\right\rangle=\left\langle\mu_{\mathrm{i}}, v_{\mathrm{i}}\right\rangle .
\end{gathered}
$$

Using (11), the score functions of the IFRPNs of failure modes $F_{i}$ can be calculated. The increasing order of the score functions represents the risk priority of potential causes. For the ship system failure analysis, failure mode with the biggest score function should be given the top priority.

\section{Intuitionistic fuzzy risk estimation of the ship system failures}

To demonstrate the applicability of the proposed method, an example about tanker system failure from a global tanker ship management company is adopted from [17]. Assume that a FMEA team consisting of five experts identifies 17 potential system failure modes on tankers (Table 4) and needs to prioritize them in terms of their failure risks so that high risky failure modes can be corrected with top priorities. Experts evaluate the risk factors of failure modes as probability of their occurrence, severity and detect ability using the linguistic terms defined in Tables $1-3$. The five experts are assigned with the following relative weights: $0.15,0.25$, $0.25,0.20$ and 0.15 . The weights of the risk factors $\mathrm{O}, \mathrm{S}$ and $\mathrm{D}$ are assumed to be $0.40,0.35$ and 0.25 . The relative weights of risk factors can be decided by experts, considering both historical data and factors which are more concerned about. For example, if the consequence of a failure is more important, the weight of its severity may be assigned with a higher value than that of others. Based on the above information, intuitionistic fuzzy RPNs of the 17 failure modes can be calculated. The score functions of the obtained IFRPNs indicate the priority order of ship system failure modes.

Table 4 shows the results of comparing the proposed method with fuzzy method [17] for the given example. The rankings of the tanker system failure modes by both approaches are almost the same, i.e. the riskiest failure is $F_{12}$ (main engine) and the least risky one is $F_{5}$ (Cargo system). The ranking of other failure modes is also consistent, e.g. the five most risky failures and three least risky ones. There are some differences in the middle rankings between approaches due to different used methods. For example, the rank of $F_{1}$ (Auxiliary engine) is seventh by the IFRPN method, while it is eighth by the fuzzy method. 
Table 4 Results of comparing proposed IF method with fuzzy method [17].

\begin{tabular}{|c|c|c|c|c|c|}
\hline No. & Failure mode $\left(F_{i}\right)$ & 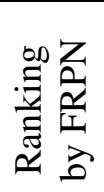 & 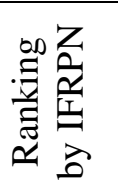 & 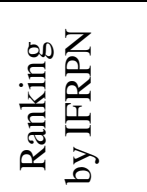 & 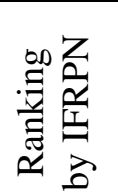 \\
\hline & & & $\pi_{j}=0$ & $\pi_{j}=0.05$ & $\pi_{j}=0.1$ \\
\hline 1 & Auxiliary engine & 8 & 7 & 9 & 4 \\
\hline 2 & Auxiliary machinery & 6 & 9 & 7 & 9 \\
\hline 3 & Boiler & 7 & 8 & 10 & 5 \\
\hline 4 & Cargo pump & 14 & 14 & 13 & 11 \\
\hline 5 & Cargo system & 17 & 17 & 17 & 17 \\
\hline 6 & Deck machinery & 3 & 3 & 3 & 2 \\
\hline 7 & Electrical system & 10 & 10 & 8 & 10 \\
\hline 8 & Emergency system & 12 & 13 & 14 & 14 \\
\hline 9 & Hull part & 15 & 15 & 15 & 15 \\
\hline 10 & Hydraulic system & 13 & 12 & 12 & 13 \\
\hline 11 & Inert gas system & 11 & 11 & 11 & 12 \\
\hline 12 & Main engine & 1 & 1 & 1 & 1 \\
\hline 13 & Monitoring system & 4 & 4 & 4 & 3 \\
\hline 14 & Mooring & 9 & 6 & 6 & 7 \\
\hline 15 & Navigation system & 2 & 2 & 2 & 8 \\
\hline 16 & Piping system & 5 & 5 & 5 & 6 \\
\hline 17 & Steering Gear & 16 & 16 & 16 & 16 \\
\hline
\end{tabular}

Meanwhile, the rank of $F_{3}$ (Boiler) is eighth by the IFRPN method, while it is seventh by the fuzzy method. Additionally, the proposed method showed that with the increasing hesitation margin $\left(\pi_{j}=0.1\right.$ related to about 3 years of practical experience) the consistency of the obtained results is deteriorating.

As can be seen from Table $4, F_{12}$ (Main engine) is apparently the failure mode with the maximum overall risk and should be given the top priority, followed by $F_{15}$ (Navigation system), $F_{6}$ (Deck Machinery), $F_{13}$ (Monitoring system) and $F_{16}$ (Piping system). The ranking can be used for the decision-making of managers, arranging the inspection and maintenance of the equipment properly, which can optimise the maintenance resources and avoid the risk.

\section{Conclusions}

In this paper, the IF method has been proposed for the risk estimation of the ship system failures, which is based exclusively on the judgments elicited by experts experienced marine engineers. The obtained results show that the proposed method is powerful and useful in dealing with imprecise and uncertain data, which are available in the such cases. 
Fuzzy methods in risk estimation of the ship system failures based on the expert... Rozmyte metody estymacji ryzyka uszkodzeń systemów okrętowych na podstawie...

Combining IFS and FMEA methods allows incorporating the hesitancy and limited knowledge of expert judgments. Compared with the traditional FMEA, the proposed method seems more effective for risk evaluation. Compared with the fuzzy FMEA, the proposed method shows more practical and flexible in describing the real-life problems. The proposed method is particularly useful in the expert investigations. It is worth noticing that subjective investigation results may (but not necessarily) be charged with greater error than objective results acquired in real operational process. Therefore, the further researches should be focused on validation of the proposed method by the objective results.

\section{References}

[1] Abdelgawad M., Fayek A.R.: Risk management in the construction industry using combined fuzzy FMEA and fuzzy AHP, J. Constr. Eng. Manage, 136 (9), 2010, 1028-1036.

[2] Atanassov K.T.: Intuitionistic Fuzzy Sets, Fuzzy Sets and Systems, 20, 1986, 87-96.

[3] Brandowski A., Frąckowiak W., Nguyen H., Podsiadło A.: Risk estimation of the seagoing ship casualty as the consequence of the propulsion loss, Proceedings of ESREL 2009 Conference, Taylor \& Francis, Vol. 3, 2010, pp. 2345-2349.

[4] Chen S.M., Tan J.M.: Handling multicriteria fuzzy decision-making problems based on vague set theory, Fuzzy Sets and Systems 67, 1994, 163-172.

[5] De S.K., Biswas R., Roy A.R.: An application of intuitionistic fuzzy sets in medical diagnosis, Fuzzy Sets Syst., vol. 117, 2001, 209-213.

[6] Herrera-Viedma E., Chiclana F., Herrera F., Alonso S.: A group decisionmaking model with incomplete fuzzy preference relations based on additive consistency, IEEE Trans. Syst., Man, Cybern., vol. 37, no 1, 2007, 176-189.

[7] Hong D.H., Choi C.H.: Multicriteria fuzzy decision making problems based on vague set theory, Fuzzy Sets and Systems 114, 2000, 103-113.

[8] Laarhoven P.J.M., Pedrycz W.: A fuzzy extension of Saaty's priority theory, Fuzzy Sets Syst., vol. 11, 1983, 229-241.

[9] Nguyen H.: A novel similarity/dissimilarity measure for intuitionistic fuzzy sets and its application in pattern recognition, Expert Systems with Applications, 45, 2016, 97-107.

[10] Papageorgiou E.I., Iakovidis D.K.: Intuitionistic fuzzy cognitive maps, IEEE Trans. Fuzzy Syst., vol. 21, no 2, 2013, 342-354.

[11] Szmidt E., Kacprzyk J., Bujnowski P.: How to measure the amount of knowledge conveyed by Atanassov's intuitionistic fuzzy sets, Information Sciences, 257, 2014, 276-285.

[12] Tan C., Chen X.: Dynamic similarity measures between intuitionistic fuzzy sets and its application, International Journal of Fuzzy Systems, vol. 16, no 4, 2014, 511-519. 
[13] Vlachos I.K., Sergiadis G.D.: Intuitionistic fuzzy information applications to pattern recognition, Pattern Recog. Lett., vol. 28, 2007, 197-206.

[14] Wang Y.M., Chin K.S, Poon G.K.K., Yang J.B.: Risk evaluation in failure mode and effects analysis using fuzzy weighted geometric mean, Expert Syst. Appl. 36 (2), 2009, 1195-1207.

[15] Xu X.Q., Liao H.C.: Intuitionistic fuzzy analytic hierarchy process. IEEE Transactions on Fuzzy Systems, vol. 22, no 4, 2014, 749-761.

[16] Zadeh L.A.: Fuzzy sets, Information and control, 8 (3), 1965, 338-353.

[17] Zhou Q., Thai V.V.: Fuzzy and grey theories in failure mode and effect analysis for tanker equipment failure prediction, Safety Science 83, 2016, 74-79.

Hoang Nguyen DSc received the MSc degree in Power Plants and Propulsion Systems in 1989, PhD degree in Marine Engineering in 2001 from the Gdańsk University of Technology. He is working at Gdynia Marine University in the Department of Engineering Sciences from 1989. His research interests include system reliability modeling, system simulation and fuzzy risk assessment, intuitionistic fuzzy sets, multicriteria decision making. He is a fellow of the PRSA. 